\title{
HUBUNGAN PENGGUNAAN GADGET DENGAN TINGKAT PERKEMBANGAN ANAK PRA SEKOLAH DI PAUD BINATAMA DESA SUNGAI PINANG KECAMATAN LINGGA TIMUR KABUPATEN LINGGA
}

\author{
Muhammad Hasani Fahtani ${ }^{1}$, Utari Christya Wardhani ${ }^{2}$, Sri Muharni ${ }^{3}$ \\ Program Studi Ilmu Keperawatan, STIKes Awal Bros Batam \\ Sunnyhiwata@gmail.com
}

\begin{abstract}
ABSTRAK
Perkembangan teknologi dan informasi mengalami kemajuan yang sangat pesat yang ditandai dengan kemajuan pada bidang informasi dan teknologi, dapat memberikan dampak terhadap tingkat perkembangan anak usia dini. Tujuan penelitian untuk mengetahui hubungan penggunaan gadget dengan tingkat perkembangan anak prasekolah di Desa Sungai Pinang Kecamatan Lingga Timur Kabupaten Lingga. Desain penelitian, populasi di Paud Binatama, variable independen yaitu bermain gadget bdan variable dependen yaitu tingkat perkembangan anak pra sekolah diukur dengan kuisioner dan DDST anak. Hasil penelitian menunjukkan bahwa bermain gadget jarang sebanyak 19 responden dimana 14 responden jarang bermain gadget dan mengalami perkembangan terlambat. Kesimpulan dari analisa data diketahui nilai $p$-value bernilai $0,01(p=<0,05)$ menunjukkan adanya pengaruh penggunaan gadget dengan tingkat perkembangan anak .
\end{abstract}

Kata Kunci : Gadget, Tingkat Perkembangan, Anak Prasekolah 


\begin{abstract}
The development of technology and information very rapid progress marked by developments in the field of information and technology, can provide improvements to early childhood development. The research objective was to study the relationship between the use of gadgets and the level of development of preschool children in Sungai Pinang Village, Lingga Timur District, Lingga Regency. The research design, participation in Paud Binatama, the independent variable is playing gadget and the dependent variable is the level of development of school children with questionnaires and DDST children Research gadgets as many as 19 respondents in which 14 respondents rarely call gadgets and difficulties of late development.
\end{abstract}

Keywords: Gadgets, Level of Development, Preschoolers 
PENDAHULUAN

Perkembangan teknologi dan

informasi mengalami kemajuan yang sangat pesat yang ditandai dengan kemajuan pada bidang informasi dan teknologi (Ismanto, 2015). Salah satunya yaitu perkembangan gadget yang semakin meluas, hampir semua individu baik anak-anak hingga orang dewasa kini sudah memiliki handphone atau smartphone. Kebutuhan komunikasi dan informasi sangat dibutuhkan bagi semua kalangan masyarakat, ditambah sekarang semakin mudah mengakses informasi dan berbagai macam fiturfitur menarik yang ditawarkan oleh jasa pelayanan gadget/smartphone itu sendiri sehingga anak-anak sering kali cepat akrab dengannya. Pada anak usia dini, boleh-boleh saja diberi gadget (Feliana, 2016).
Penggunaan gadget secara terusmenerus akan berdampak buruk terhadap pola pikir dan perilaku anak dalam kehidupan kesehariannya, anakanak yang cenderung terus menerus menggunakan gadget akan sangat tergantung dan menjadi kegiatan yang rutin dalam aktifitas sehari-hari dalam hal ini sering kali anak-anak lebih memilih bermain gadget sehingga menyebabkan anak-anak menjadi malas bergerak dan beraktifitas. Mereka lebih memilih duduk di depan gadget dan menikmati permainan yang ada pada fitur-fitur tertentu dibandingkan berinteraksi dengan dunia nyata". Hal ini tentu berdampak buruk bagi perkembangan dan kesehatan anak terutama di segi otak dan psikologis. Dampak negative lain juga dapat menyebabkan kurangnya mobilitasi sosial pada anak, mereka 
lebih memilih bermain menggunakan gadget dari pada bermain bersama teman sebayanya tidak jarang kita lihat anak mengalami kesulitan untuk berkonsentrasi karena otak anak sudah diporsir pada dunia yang tidak nyata (Ameliola, Nugraha, 2013)

Kejadian seperti ini harus menjadi perhatian bagi berbagai pihak untuk meningkatkan kewaspadaan terhadap anak-anak dalam penggunaan gadget sebagai media komunikasi dan bermain. Khususnya dari lingkungan keluarga yaitu orang tua sebagai institusi dalam pembentukan karakter dan tumbuh kembang anak. Peran orang tua harus selalu dilakukan, dengan cara mengontrol setiap fiturfitur yang ada didalam smartphone, orang tua harus selalu berkomunikasi dengan anak-anaknya dan membatasi penggunaan gadget dengan batasan- batasan waktu untuk anak menggunakan gadget, misalnya sehari anak hanya boleh bermain gadget selama satu jam tentu fitur-fitur yang mendukung perkembangannya (Fadilah, Ahmad 2011).

Berdasarkan latar belakang tersebut peneliti berminat melakukan penelitian dengan judul Hubungan Penggunaan Gadget dengan Tingkat Perkembangan Anak Prasekolah Di Paud Binatama Desa Sungai Pinang Kecamatan Lingga Timur Kabupaten Lingga METODE PENELITIAN

Rancangan penelitian yang digunakan dalam penelitian ini adalah dengan menggunakan metode kuantitatif, Sampel penelitian adalah anak pra sekolah di Paud Binatama. "Teknik dalam pengambilan sampel dalam penelitian ini adalah purposive 
sampling. Purposive sampling menurut Sugiyono adalah teknik penentuan sampel dengan pertimbangan tertentu (Sugiyono dalam Vina 2018). Kriteria Inklusi Bersedia menjadi responden, seperti Orang Tua yang mempunyai anak di Paud Binatama (Usia Anak 3-6 Tahun). Kriteria Eksklusi Tidak bersedia menjadi responden seperti Orang Tua yang tidak mempunyai anak di Paud Binatma. Apabila bila $\rho$ value (nilai signifikan) $\leq \alpha(0,05)$ maka Ho gagal ditolak, artinya bahwa ada hubungan penggunaan gadget terhadap perkembangan anak. Apabila bila $\rho$ value (nilai signifikan) $\geq \alpha$ $(0,05)$ maka $\mathrm{Ha}$ diterima, artinya bahwa tidak ada hubungan penggunaan gadget terhadap perkembangan anak.
HASIL DAN PEMBAHASAN

Penggunaan Gadget dengan tingkat perkembangan anak prasekolah di Paud Binatama

Desa Sungai Pinang Kecamatan Lingga Timur

\begin{tabular}{|c|c|c|c|c|c|c|}
\hline \multirow{3}{*}{$\begin{array}{l}\text { Penggunaan } \\
\text { Gadget }\end{array}$} & \multicolumn{6}{|c|}{ Tingkat Perkembangan } \\
\hline & \multicolumn{2}{|c|}{ Normal } & \multicolumn{2}{|c|}{ Terlambat } & \multicolumn{2}{|c|}{ Total } \\
\hline & $\sum$ & $\%$ & $\sum$ & $\%$ & $\sum$ & $\%$ \\
\hline Sering & 0 & 0 & 6 & 19.3 & 6 & 19.3 \\
\hline Jarang & 6 & 19.3 & 13 & 42 & 19 & 61.4 \\
\hline $\begin{array}{l}\text { Sangat } \\
\text { Jarang }\end{array}$ & 6 & 19.3 & 0 & 0 & 6 & 19.3 \\
\hline Total & 12 & 38.7 & 19 & 61.3 & 31 & 100 \\
\hline $\begin{array}{l}\text { Hasil } \\
\text { SPSSS }\end{array}$ & \multicolumn{6}{|c|}{$P=0,001 \quad \alpha=0,05$} \\
\hline
\end{tabular}

Sumber: data primer 2020

Berdasarkan tabel dapat diketahui bahwa sebagian besar dari responden dengan jumlah $19(61,4 \%)$ responden dimana dimana 13 responden (42\%) jarang bermain gadget dan mengalami tingkat perkembangan lambat jumlahnya lebih banyak dari yang jarang bermain gadget yang mengalami perkembangan normal yaitu sebanyak 6 responden $(19,4 \%)$. Melalui uji statistiq dengan 
Pearson Chi Square didapatkan nilai $\mathrm{P}$-value $=0,01$ yang berarti $\mathrm{p}$-value $<$ 0,05 sehingga hipotesa null (Ho) ditolak dan $\left(\mathrm{H}_{1}\right)$ diterima. Ini menunjukkan bahwa adanya hubungan bermain gadget dengan tingkat perkembangan anak usia dini.

\section{HASIL DAN PEMBAHASAN}

Berdasarkan hasil penelitian yang dilakukan dapat diketahui bahwa anak yang jarang bermain gadget lebih banyak tingkat perkembangan terlambat terlihat dari data tabulasi soal nomor 1 tentang durasi bermain gadget yang menjawab paling banyak mejawab jarang dengan hasil jawaban pertanyaan no 2 tentang penggunaan bermain gadget untuk main game paling banyak yang menjawab sering, selain itu pada responden yang durasi bermain jarang merespon pertanyaan no 9 tentang penggunaan gadget untuk memudahkan mengingat warna dan gambar paling banyak responden menjawab jarang, sehingga penggunaan gadget pada anak yang berdurasi jarang mengalami dampak negative karena terjadi kesalahan dalam penggunaan gadget

Menurut penelitian bermain gadget pada anak usia dini hanya digunakan untuk bermain game, melihat video di youtube saja sehingga mereka tidak aktif dalam berinteraksi dengan lingkungan sekitarnya sejalan dengan teori Ismanto dan Onibala, 2015 dimana mereka lebih memilih bermain menggunakan gadhget dari pada bermain bersama dengan temanteman dilingkungan sekitar tempat tinggalnya, sehinga interaksi social antara anak dengan masyarakat, lingkungan sekitar berkurang. 


\section{KESIMPULAN}

Berdasarkan hasil penelitian yang telah dilakukan oleh peneliti, maka dapat ditarik kesimpulan sebagai berikut:

1. Bermain gadget pada anak usia dini di Paud Binatama sebagian besar jarang bermain gadget.

2. Tingkat perkembangan anak usia dini di Paud Binatama sebagian besar mengalami tingkat perkembangan anak terlambat.

3. Ada hubungan antara bermain gadget dengan tingkat perkembangan anak usia dini di Paud Binatama.

DAFTAR PUSTAKA

Ahmad Susanto, 2011. "Perkembangan Anak Usia
Dini”, Jakarta. Kencana Prenada Media Group

Aisyah Siti, Dkk (2010) "Perkembangan Konsep Dasar Pengembangan Anak Usia Dini”. Jakarta. Universitas Terbuka

Ameliola, Nugraha.

"Perkembangan Media Informasi dan teknologi Terhadap Anak dalam Era Globalisasi”. Diakses dari http://icsis.files.wordpress. com/2013/09/2013-0229 pada tanggal 10 Januari 2020

Anggraeni, D.M \& Suryono. (2013). "Metodologi Penelitian Kualitatif dan Kuantitatif dalam Bidang Kesehatan”. Yogyakarta:Nuha Medika

Arikunta, S. 2010. "Metodologi Penelitian Kesehatan”. Jakarta: Rineka Cipta

Fadilah, Ahmad, 2011. "Pengaruh Penggunaan Alat Komunikasi Handphone (Hp) Terhadap Aktivitas Belajar Siswa SMP Negeri 
66 Jakarta Selatan. Kuantjojo, 2010, Strategi Skripsi." Program studi Pembelajaran Untuk Anak Ilmu Tarbiyah. FKIP. Usia Dini

Universitas Islam Negeri Syarif Hidaytullah. Jakarta

Ferliana, Jovita Maria, (2016) “Anak dan Gadget Yang penting Aturan Main".

Marimbi, Hanum, 2010. Tumbuh Kembang, Status Gisi dan Imunisasi Dasar Pada Balita, Yogyakarta: Nuha Medika

Ghozali, Imam, 2011. “Aplikasi Analisis Multivariate Dengan Program SPSS" Semarang: Badan Penerbit Universitas Diponegoro

Ikatan Dokter Anak Indonesia (IDAI) Kumpulan Tips Pediatrik. Jakarta: Badan Penerbit Ikatan Dokter Anak Indonesia

Ismanto, Yudi \& Onibala, Franly. $2015 . \quad$ "Hubungan Penggunaan Gadget dengan Tingkat Prestasi Siswa di SMA Negeri 9 Manad”. Ejournal Keperawatan Volume 3. FK Unsrat Manado

Kemenkes RI. 2013. "Riset Kesehatan Dasar. Jakarta: Kemenkes RI”.

Nurrachmawati, 2014. Pengaruh system Operasi mobile android pada anak usia dini. Jurnal pengaruh system operasi mobile android pada anak usia dini. Jurnal Pengaruh Sistem Operasi Mobile Android Pada Anak Dini. Universitas Hasanuddin. Makasar

Notoadmodjo, Soekidjo (2010) "Metode Penelitian Kesehatan. Jakarta: Rineka Cipta”.

Notoadmodjo, S. 2012. "Metodologi Penelitian Kesehatan”. Jakarta: Rineka Cipta Saryono (2010). "Kumpulan Instrumen Penelitian Kesehatan”. Yogyakarta: Nuha Medika 
Triastutik, Yeni. 2018. "Hubungan

Bermain gadget dengan tingkat perkembangan anak usia 4-6 Tahun (Di Taman Kanak- Kanak Bina Insani Desa Candimulyo Kecamatan Jombang Kabupaten Jombang)".

Wong, L. Donna. 2009. Buku Ajar Keperawatan Pediatrik. Vol. $1 . \quad$ Edisi 6. Jakarta : EGC.

Yulianti, Dwi (2010). Bermain Sambil Belajar Sains di Taman Kanak-kanak.

Jakarta: PT Indeks.

Yusuf, Syamsu. 2009. Ps ikologi Perkembangan Anak dan Remaja. Bandung : PT. Remaja Rosdakarya.

http://eprints.undip.ac.id/55141/2/Skri

psi_Meta_Anindya_A._G._(22

201132005

$0)$.pdf. 